\title{
Political Cartographies in Aquarius
}

Tom Winterbottom

The team behind Kleber Mendonça Filho's 2016 film, Aquarius, garnered significant attention at that year's Cannes Film Festival, and it was not only that the film was well received by critics and audiences. The film's May presentation on the French Riviera coincided with the suspension from office on 12 May 2016 of former Brazilian president Dilma Rousseff, who was later impeached and removed from power. The cast and crew posed on the red carpet to make public statements about the political unrest in their country, holding up signs in English, French, and Portuguese reading "Brazil is not a democracy anymore," "Dilma, we will resist together with you," "54,501,118 votes set on fire," "The world cannot accept his illegitimate government," and "Save Brazilian Democracy!". The film's subject is contested space: an apartment block in Recife under pressure from developers. The film, once completed and released as a work of art, then came to occupy a contested space in the cultural landscape of Brazil. As a result of this latter process, Aquarius became deeply politicized even though there is little explicit reference to a political context in the film itself. Rather, in the process of its politicization in the public domain, viewing the film as a political piece became increasingly relevant and urgent. On the one hand, it served as a vehicle to capture a moment of acute disquiet and unrest in the country more broadly and, on the other, it also became a scapegoat for its political critics. With this is mind, and in order to unpack the multiple contested spaces that the film presents, it is worth examining the film and its storytelling techniques that permit such a viewing before further analysis of the reaction to and reception of the film in the public domain.

In the press conferences and interviews associated with the premiere of the film, it was clear that the filmmakers understood what was happening in Brazil to be a coup d'état, an ousting of a legitimately and democratically elected president by powerfully backed forces of opposition in the political sphere. Rousseff, the head of a coalition government and a member of the Worker's Party (PT), was ousted by her vice-president Michel Temer, a member of the Brazilian Democratic Movement Party (PMDB). Temer assumed temporary control in May

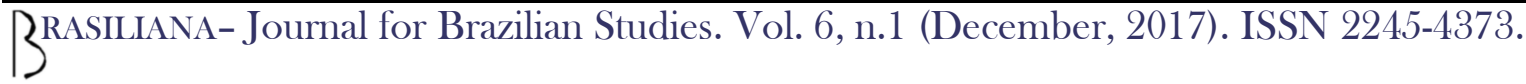


and then took over as president for the remainder of her term (until 2018) when the impeachment was confirmed in August 2016. Temer, who had campaigned alongside Dilma in two successful runs for president, emerged as the most viable candidate to replace the 14-year rule of the PT given his experience and prominence. As such, after the PMDB broke the coalition in March Rousseff's political support was fundamentally undermined; through legal channels, Rousseff could be toppled in a process driven by Eduardo Cunha ${ }^{1}$. Temer could then be installed in power to redefine the cabinet and establish a new coalition to run the country. It was a move that placed significant power in Temer's hands and put the PMDB at the head of a complex coalition while diminishing the presence of the PT across federal government ${ }^{2}$. The film directly and unexpectedly coincided with the end-period of PT rule in Brazil, a moment that marked a distinct shift in the Brazil's political climate.

\section{Political Atmosphere}

None of this occupies the direct subject matter for Aquarius. For a start, filming took place in 2015 while these developments remained under the surface. The subject is instead the city of Recife and one apartment building and how a resident fights to remain in her apartment under various pressures exerted on her. Those events in Brazil's political sphere coincided with the prominent premiere at Cannes in May 2016 and its broader release a few months later, and somewhat inadvertently brought attention to the filmmakers and their political opinions as well as encouraging the film to be seen in a political light and as a piece of political cinema. As such, one can watch the film and see how it subtly captures a certain political atmosphere in terms of its subject matter which lingers on the question of contested space. One can also consider the film according to its broader presence in the country's political realm as a cultural product following its international premiere and wider release. Unsurprisingly, both its

\footnotetext{
${ }^{1}$ Cunha has been one of Brazil's most prominent-and corrupt - power brokers for years. He is also a PMDB member, a former president of the chamber of deputies, and federal deputy for Rio de Janeiro, and has since been banned from politics for corruption and money laundering and sentenced to a 15-year sentence, accused of keeping US $\$ 40$ million in bribes in secret bank accounts.

${ }^{2}$ Temer had his own impeachment process shelved by Cunha while the latter was still in a position of political power. Temer himself later faced various corruption charges, particularly when tapes of recorded phone calls emerged of him greenlighting a bribe to keep a jailed politician — Cunha—quiet about an elaborate kickback and corruption scheme.
}

BRASILIANA- Journal for Brazilian Studies. Vol. 6, n.1 (December, 2017). ISSN 2245-4373. 
showing at Cannes and distribution throughout Brazil generated heated debate precisely for this unanticipated depth of politicization. It became the most political film of recent years, at least symbolically.

The reaction of the cast and crew on the red carpet and in an array of subsequent interviews served to politicize Aquarius according to the broader national context, transforming it, at least in part, into a political film-but in a multifaceted and complex manner, going beyond the story and what we see on screen. This film and Mendonça Filho's previous work, O som ao redor (2012), present small communities in the throes of change and development and explore the intimate, community-level politics of these places and the relationships of power set in close quarters. Both films are set in Recife, a rapidly-growing northeastern city that is subject to real estate speculation and where the old city is being added to, amended, destroyed, expanded, and further stratified-along socioeconomic lines, becoming increasingly divided and unequal-in construction of the "new" metropolis of millions.

There are three factors worth exploring in Aquarius: the story and storytelling techniques employed by the filmmaker, the film's release and its context, and the public debate that surrounded the film's reception, much of which took place on social media. These three factors - the film, the context of its release, and its reception-generated a politicized discourse that enveloped the film, despite its plot focusing solely on a small-scale story of one woman in one apartment in one building in one neighborhood in one city. The spatial aspects at play are vital to this viewing of the film. The choice of where and how to set the film, as well as how to tell the story and portray the characters, lend a somewhat claustrophobic intimacy to the film that leaves many narrative threads to be resolved by the viewer. Nonetheless, this situational microcosm-a trait of this and the director's previous film-is just the tip of the iceberg that alludes to and implies larger, unshown critiques. That the political context in Brazil changed so significantly between conception, filming, and release only served to heighten the effect of unease and of lingering, malign forces out of the protagonist's control ${ }^{3}$. In the process, these elements made Aquarius among the stand-out films of the year as both a work of art and as a (somewhat accidental) cultural statement.

\footnotetext{
${ }^{3}$ The insecurity continues: as of 2018 , the political situation leading towards the elections remains deeply complex and contested as Brazil lurches into an extended political crisis.
}

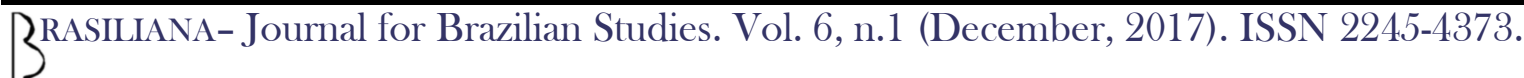




\section{Sparse Storytelling}

Aquarius is essentially the story and character study of an aging matriarch. Clara (played magnificently by Sonia Braga) is a retired music critic who lives in an old building (named Aquarius) in a wealthy seafront neighborhood in Recife. The other tenants have left their apartments, taking up the tempting and above-market prices offered by a development company who want to knock down the apartment building and replace it with, one assumes, a new apartment tower block of the type that is by now omnipresent in Recife. It is a replacement of the old with the new, the outdated with the modern, the old lady with new tenants, a forgetting of the past and an opening to the future. These are all tensions that are unfolded according to a simple spatial pressure: the desire to destroy one building and replace it with another, for financial gain and shaped by largely unknown and seemingly malicious forces. Our view of Clara's story unfolds mostly in and directly around this building: she does not want to move under any circumstances and does not need to; this is her home. She feels the pressure from all sides-from friends, family, developers, and others unknown-but stubbornly takes on the fight, staying despite the best efforts of almost everyone around her. It is a film about Clara and the story of her life in that one apartment in that one building. However, the intimate focus on the story of Clara and her fight, and the manner in which the director tells that story, also indicates the presence of very powerful-yet unvoiced and unknown-presences off-screen.

As a result, though the story unfolds on such a microcosmic level, only from the perspective of Clara and with little voice given to other characters, the film implies so much, feeling loaded with meaning, leaving unspoken and unshown the broader machinations at play that are implicit in the narrative. It is, then, left up to the viewer-in a reader-response modeto make the connections and imagine the rest of the iceberg that links this film to a broader and relatable context. That context varies, of course: for some it might be the story of family unit, the story of urban change, a critique of developmental capitalism, or about the importance of the powerful feminine voice that Clara represents. Its symbolism is wide ranging, its interpretations and implications multiple. The story, however, is simple.

The city of Recife is the vital landscape for Aquarius, as it is in $O$ som ao redor. Also similar to that film, Aquarius begins with black-and-white photos: an unconfirmed and unexplained allusion to a different time. They show images of the old Recife beachfront and the

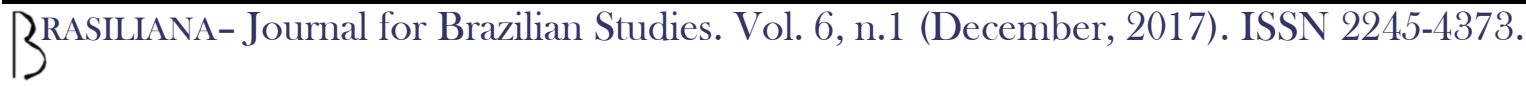


neighborhood that is the setting for the story, indicating how the city has changed and is changing, the identifiable throngs of white tower blocks progressively rising up as the years pass. In the first part of the film, "Clara's Hair," set in 1980, we see a birthday party for Clara's aunt, Tia Lucia, with a shorthaired Clara and her husband giving a speech in celebration of their relative. We learn that Clara had breast cancer the year before and had lost her hair in the treatment. Her husband dedicates part of his emotional toast to Clara, talking of his love for her and his fear that he would lose her to cancer. The aunt, an inspiration to Clara, loses herself in moments during the party and focuses on an old chest of drawers, a recurring and nostalgic object in the film, symbolic of times passed (not unlike the photos in the titles), that will be passed down to Clara and end up in her apartment. It is a homely scene, of family and friends and objects, set within the walls of the apartment and reiterating the value of house, home, and family: together they sing, "We commemorate the great day that you are celebrating today! Be the house where you dwell the abode of joy, the refuge of happiness. Happy birthday!" The house is a protected and respected space, a place of family, observance, and memories.

The narrative then jumps forward more than thirty years, with a retired Clara still alive and now alone, living in a historic apartment block on the seafront. She goes to the beach, with the camera focusing in on a "beware of the sharks" sign at the beach's edge (a device that also featured in $O$ som ao redor, its symbolism not too hard to ascertain), for a swim before returning home where she is interrupted by a knock at the door. She is greeted by the winning smiles of the representatives of a development company, Bonfim Engenharia, who are there to make her an offer. It is, in fact, a counter-offer: we learn that they are trying to convince her to leave the apartment and that she has offered to buy the apartment downstairs from hers, and instead they offer to buy her apartment significantly above market rate with a new and improved proposal. Clearly resistant, the developers - a father and son team, this being the son's first big project as heir apparent-try to convince her. To do so, they detail the new aspects of the offer: in recognition of its current name "Aquarius," the new development would have the name "New Aquarius" instead of the previously proposed "Atlantic Plaza Residence" - presumably a gesture, on their part, to maintain something of the essence of the old building. She recognizes the awkward hollowness of their suggestion, rebutting them and making it clear that this is where she lives, has lived, and has no desire to leave. She is retired, the apartment is paid off, and she is financially solid, and the residence seems to mean a great deal to her; as such, she rejects their paperwork. Following this is a wonderfully awkward scene of 
disconnectedness in which the younger developer, Diego, tries to slide the papers under the door, and she slides it back, and so on. The developers, all forced smiles on the surface, know they have a fight on their hands, someone blocking their way. These scenes establish Clara's apartment and home as the central space of the film. It is the discursive space in which the story unfolds and also the space of contestation that implies dynamics - of space, power, capital, and so on - that has relevance beyond the limitations of that one building and this one story.

In the second part, "Clara's Love," we learn that her husband died in 1997 and that she is a widower of seventeen years. Given Clara's earlier breast cancer, apparently severe and leaving her close to death, it is somewhat surprising to learn that her husband was the one who died early (and that in fact he died and that they did not divorce: in the opening scenes at the birthday party the director portrays their personalities as being somewhat distant). Again, however, we see in Clara a strong commitment to her home and to the husband with whom she lived there, happily and with fond memories. Here and elsewhere in the film there is a strong nostalgic impulse that is part of her character and that makes rejecting the development company's advances a straightforward decision. She has irked her neighbors-who have already moved out, accepting the offer-as some of their payments will be delayed until she leaves. She has also drawn subtle intrigue from her sacred family unit, who are more tempted than Clara by the offer on the table and what it could mean for them.

Soon, however, things turn quietly and immorally malicious: we remain firmly focused on Clara and her life, learning more about her and her family, but around her the forces at play soon start to have an effect. The development company, unexplained, moves mattresses into the other apartments and rents it out short term to partiers who, in one instance, come back there after a night out, listen to loud music, and have an orgy just down the hall. She goes to investigate, peering through a crack in the door. Rather than be perturbed, however, she smiles and returns to her apartment to listen to loud music, smoke some marijuana, drink a bottle of wine, and finally elicit the company of a male escort that her friend has recommended to her.

Given the offer, the fact that she now has no neighbors and that untoward things are happening unannounced in an attempt to force her out, people around her (including family) wonder whether she should stay. She stubbornly maintains her position on the moral high ground and defined by the complex feeling of saudade for the space that she occupies and what it represents. Taking her out of that space would remove a part of her and her memory, her saudade, a sensation that the film produces by keeping us in and around the building for

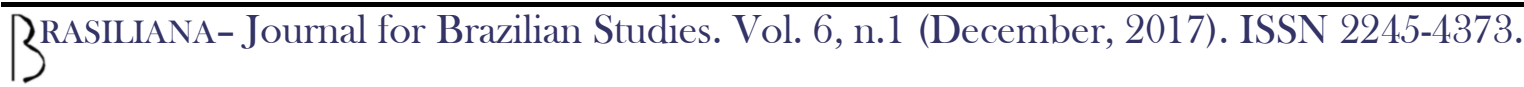


almost the entire running time. The company is getting on the wrong side of her and in this character portrayal we are intimately privy to Clara developing a resistance to these unwanted forces that challenge her autonomy in her older age and-seemingly-with nothing to lose. Her kids question the value of the old edifice and worry about her living alone in a ghost building: they cite concerns about safety and security, with their financial motivations lingering.

Clara is aware that she is perceived as eccentric and somewhat abnormal for her obstinate and strong reaction to the developers' offer. Given her commitment to family and home, when she learns that her daughter went to the developers to find out about the offer, behind her back and with financial motivations clearly in mind, Clara is riled: it endangers her feeling and expression of saudades and it risks her pride, chipping away at her sense of worth and desired legacy. It also gives her something to fight. She has no desire or will to move and so is set on rebutting the pressure that comes from malignant forces outside of her personal context and control. It becomes, then, a battle of wills, an invocation of the David and Goliath story in a contemporary Brazilian context. We are shown Clara as a strong, stubborn character who will not be swayed; for her, it is not a difficult decision, and yet there is always the feeling that something, unshown and narratively undeveloped, is at play around her as we learn more about her family, her friends, and her past. The attack on her emotional and physical space is being waged by a silent, absent beast that lurks, threateningly, off screen: who is behind it, and why, are the questions that emerge, making us wonder what exactly is at stake in the confines of the film and also beyond its walls. Is it as simple as one company making some quick money or does it imply a broader culture that implicates ways of conducting business, corruption, and power-political relationships at large? There is a lot more at stake, it seems, than the microcosm of Clara's apartment, but those are connections that the director leaves up to the viewer.

In the third part, "Clara's Cancer," we see an aggressive sickness accelerate, but not what we might expect given the protagonist's medical history. Diego, the heir to the property firm, starts a tactical, malignant takeover of the building: there is a touch of the absurd, for example, when it is rented out to a religious gathering. Everyone advises her to move, although no one seems to talk about the money at stake for the family, the developers, and for her. Instead, they only talk about security, safety, a "woman of her age," and so on, with the financial impulse and probable actual motivations and machinations remaining unvoiced. In one scene showing one of their infrequent encounters in the building's car park, Diego mentions that she should 
think about her family and their futures, the early smiles now all gone and the (passive) aggression plain to see. Clara, riled by this more personal attack, launches a diatribe about his white privilege and elite status (curated, we learn, while studying business in the United States), and the gloves are now off. Diego, in an attempt to take the moral high ground, jousted Clara in the heart by attacking her strength, her pride, and her loyal familial sensibility, traits that-in her view of the world-are connected to her home, an object that for her is the manifestation of her life, her memory, her saudade for what she has been and is. In a show of resilience and expression, she pays out of pocket for a fresh coat of paint on the building's seaside façade, an action that leads the developers to start the motions to take her to court for illegally painting it and not seeking the approval of the owners-that is, the development company - of the other apartments. "This is so Pernambuco," she says, "this is so Brazilian."

Later, at lunch with the owner of a local newspaper (she is also well connected), he asks her why she doesn't just leave, to not get involved, and to accept their offer to avoid being taken to court and avoid any further problems. It is as though he knows much more than he will say openly, that he is aware of what is at stake and the sinister machinations at play, and yet they remain unknown to the viewer. Is she being blackmailed from all sides, or is it something of a veiled threat from the newspaper man? By now, however, she perseveres, unwilling to let him off the hook and we get some resolution as the camera stays with their conversation long enough for us to get a hint of dramatic plot development: he gives her some documents, the exact contents of which the viewer never knows. We get the tip of the iceberg but never anything more; the forces really at play remain unknown and left to our imagination. The papers seem to have dirt on the development company, maybe just evidence of malpractice but also, hypothetically of course, could contain more sweeping insider information about their dealings, ways of conducting business, and even implicating more powerful political figures regarding corruption. Soon after, on entering her apartment building, she is approached by two construction workers - are they going to attack her? - who slink up to tell her, fearfully, about a job they were given while she was away on a trip. We do not hear the details of their conversation, only learning that she should take a look at some of the other apartments. In the first of the film's two main climactic moments, she goes to see the apartments, which she finds to be riddled with termite nests that-we presume - the development company has planted there in order the get the building demolished. The apartments are ruined and disgusting, with the crackling sound of millions of termites eating away the very fabric of the building that is

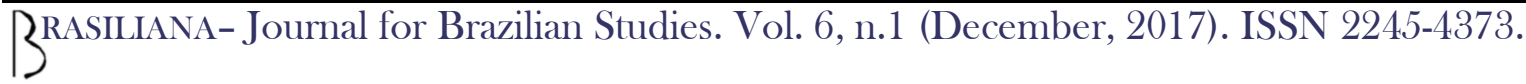


so important to Clara. In the final scene, and its second climactic point, Clara descends on the offices of the development company with the papers and a roller suitcase with a demand to meet with them: she knows it might not stop them but if she is able to cause them "just a single headache," after they have caused her so many, then she will be happy. "Are you traveling?" Diego asks jovially and in reference to the suitcase, perhaps hoping that finally she is leaving. She ignores him, instead presenting them with the papers she has received (to their visible shock and surprise) and then picking up the suitcase, putting it on the table, and unzipping it to dump the contents-a termite nest-onto the table. The film ends.

\section{Don't show, don't tell}

In this film as in Mendonça Filho's previous work, the narrative does not resolve: the climactic point is left unexplored. We do not know anything about the details in the papers that she has, nor about what happens after that last scene: there is no happy ending or resolution, and it is left for the viewer to make their own connections as to the conclusion of a story that seems cut off at a point just when the protagonist has found a way in. In $O$ som ao redor, the director uses the same technique: the film finishes right after we learn about the real reason Clodoaldo, a private security agent, chooses a particular street to set up his business. Years earlier, the man who owns most of the property on the street where Clodoaldo now works killed his father, opening up the storyline to the narrative thread of a thriller just when the film ends. In both films, we are not told what to think, nor are we barraged with images of retribution, downfall or victory. Rather, the narrative ends on this cliffhanger à l'auteur: in Aquarius, Clara arriving in the developers' offices is a narrative climax and the film's non-resolving terminal point, with no happy ending or tragic conclusion. This is not, therefore, a story that can be easily wrapped up.

These bigger stories and broader implications remain purposefully undeveloped in favor of more intimate stories that tell explorative tales about individual lives and how they are looped into broader political and social relationships, and even if those ties remain largely unspoken they are ever-present in the narrative, lurking off screen. In Aquarius, the intimate family story centered around Clara is underpinned and defined by the subtle presence of an evil development company, hints of corruption, blackmail, and chance meetings that all

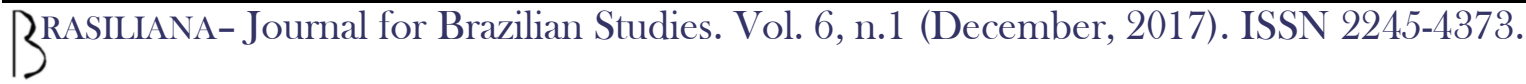


challenge the protagonist's physical and emotional space. Yet, how it resolves-who wins, if such a thing is possible for the individual, and how - is left to the viewer.

In his narrative films, then, Mendonça Filho generates a sense of unease and disquiet that leaves the viewer to arrange and ascertain the (broader) implications: the development company is a lingering, lurking, and malign enterprise about which we are purposefully uninformed, and their actions-in planting the termites, for example, or their misdeeds that are probably contained in the documents that Clara receives-are covered up. The director only presents to us a fraction of the story and invites the viewer to make those connections. Through this technique in which the explicit drama and associated explanation is left off screen, Mendonça Filho creates a world that relies on subtle dynamics and meandering, local stories that avoid glamorization, romanticization, or melodrama. In their place, there is instead a sensation of malign enterprise and forcefully capitalized and inequalizing development that, if you are willing to extrapolate, lie nearer to the wild heart of contemporary, postmodern Brazil. By telling this intimate and microcosmic story set in a growing city, the director implies a moral framework of Brazilian society that stretches far beyond the limit of Clara, of the building, and of Recife.

Upon the film's release, and given the political context in which it came out, the implicit political gestures concerning corruption, development, and big business took on a more explicit timbre. Yet, from the plot detailed above it is hard to call this an overly political film or a direct critique. However, in part for its content and in part for its reception, and the two in dialogue in the context of its release, viewers and critics were inspired to make connections between the film and its political implications, making it a contested cultural object in the socio-political realm. Technically, Mendonça Filho allowed for these links to be made by adopting a "don't show, don't tell" approach.

It was Ernest Hemingway who most famously considered the image of the "iceberg" as a central feature of a theory of omission, particularly in Death in the Afternoon. In this non-fiction work, an elegy to the bullfighting that so impassioned Hemingway, he makes clear that overt description, exposition, or summary that feeds the reader with images is too blatant and superfluous. After all, and as reader response literary theory would contend, it is the reader who makes the connections and finds their meaning according to the matter presented to them in the text. More than that, however, it goes beyond mere connections that the text makes for the reader or that the author "creates" for the reader to "interpret." As Wolfgang Iser

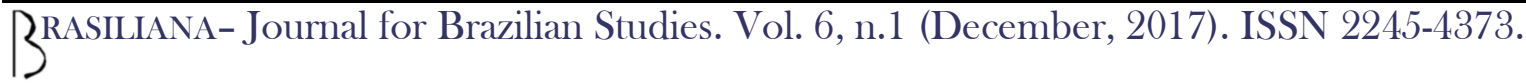


proposed, there can be a development of reception theory that considers the "aesthetic response" of the reader (Wirkungstheorie) that differs from other theories of reader response (Rezeptionstheorie). In Iser's thinking, there is no objective meaning buried in the text and there is no one way to read the text; instead, he proceeds from the position of an ideal "implied reader." As such, literature produces effects of meaning for the reader in a virtual space generated between reader and text in which there are large portions left unexplained, perhaps because of (structural) limitations in aptly conveying broad and wide-ranging subject matter that is full of implications and possibilities beyond a unified meaning or one simple reading. For Iser, this gap in between "implies" the reader and requests their interaction in processing and experiencing the events that make up an individualized meaning of a text.

These are two different views from different perspectives, from Hemingway and Iser, on the same subject. The first is from the author's perspective about not feeding tightly wrapped, no-room-for-interpretation stories to a reader: the impulse is to leave the reading, and the creation of meaning by making connections, to the reader. The second is about how that reading takes place: when presented with a narrative crafted by an author who does not describe and explain everything, making loose ends an inherent feature, the reader has to work with the iceberg that the author has created, stepping out of a mode of understanding in which meaning is shaped and consumed and into the interpretative frames of reference that a literary text generates. In this interaction, it is in the space between the text and the reader where meaning takes root, and so it is that fiction which allows for alternate worlds to be created with the virtual reality of the text's meaning. Aquarius offers a stunning cinematic example of this technique, in which Mendonça Filho crafts a virtual reality shaped closely around Clara's life but where her story has many loose ends, allowing for the space between viewer and film to become discursively important. This space became remarkably open and robust given the context in which the film came to audiences and critics. Receiving and responding to a text allows for the imagination to flourish and to move beyond the constraints of the reading experience and beyond the plot points presented in a fictional work. In other words, the author omits aspects of a narrative to allow the reader to read and not be fed meaning, perspective, or opinion. The author can lead that way, but it is up to the reader to make the leap, a process that changes according to who is doing the reading and making one overarching interpretation or theory impossible and allowing for multiple angles from which to critique literature.

In literary thinking, the theory of omission is often used synonymously with the idea of 
"show, don't tell," the notion that writers elaborate only small details in their descriptions so that the reader can read this grouping of details and imagine, away from the text, what is being alluded to and its meaning without the thing ever actually being written in the pages of the book. Clearly, with cinema and visual culture, the "show" part of "show, don't tell" encounters a stumbling block. (And, for that matter, having just taken this excursion into literary theory, the terms "reader" and "text" also bring with them obvious potential complications in an essay on cinema). But, and as reader response theory confirms, these terms are not limited materially to a text and nor only to a reader; rather a "text" can be a book, film, or other creative work (of a literary sensibility) and the reader can be understood according to the broader, and here more applicable terms, "audience" or "viewer." As such, the meaning is not inherent in the film (or, for that matter, in other cultural products) itself but is created in the relationship between viewer and film, a space in-between that is nourished by the tip of the iceberg that the author (or director) presents.

In the case of Aquarius, remarkable coincidence also played its part. While it was filmed and produced before the most recent political crisis in Brazil, its premiere at Cannes and the red-carpet protest saw a concurrence between the socio-political context in Brazil and the artistic, directorial guidance of the film and its subject matter. In other words, the conditions of the film's release and its viewing is hard to consider without also thinking about the larger context of Brazilian sociopolitical and socio-cultural context. Having discussed how the director achieves a potentially politicized viewing of the film from within, it is worthwhile to think about how the film, as a cultural product and object in cultural discourse, became politicized from the outside. "To me the film is about a city, a building and the woman that lives in it," Sonia Braga said in an interview with the New York Times, "that is the simplicity of this story." The story may be simple, about a contested space in a growing city, but the film also makes implications about what lingers under the surface and lurks off screen, and it became much more significant than that simple story that Braga performed as it fought for contested space in the cultural landscape of Brazil after its premiere and in the context of embattled political upheaval. As a result, while the techniques employed by the director made allowances for multiple interpretations and ambiguity, the film's multiplicity of interpretations were largely left behind as the film, its filmmakers, and the timing of its release imbued the whole enterprise with an unexpected prominence, presenting the film as a cultural object representative of those who had made it and the opinions they held. The film became laden

ßRASILIANA- Journal for Brazilian Studies. Vol. 6, n.1 (December, 2017). ISSN 2245-4373. 
with meaning that generated a platform for a wide-reaching and fiery political debate and a story of artistic censorship.

\section{Political Viewing}

When thinking about the film not in terms of its subject matter but as an object to be understood in its sociocultural context, the protest at Cannes marked only the beginning. The politicization developed into a public discourse through an exchange of opinion pieces and, inevitably, on social media. In August 2016, as Rousseff was removed from office following her successful impeachment, and as Aquarius prepared for its wide release in Brazil after the May premiere at Cannes, the Justice Ministry in Brazil gave it an age-18 classification, the highest and most restrictive possible (for "complex sexual situations"). This was a political maneuver, an attempt to stifle access to the film in cinemas at a sensitive time and when the filmmakers were known to be against the incoming government and to limit the overall impact of the film in the box office and the wider cultural landscape.

The censorship was obvious and picked up on by the film's distributor in Brazil, which made the point that it was only in the film's home country that the highest classification had been imposed by the state and that it was going to be shown and distributed in over sixty countries worldwide with a lower rating. The distributor's appeal to reduce the viewing age to 16 was denied on the basis that the film contained scenes of sex and drugs (when, as I mentioned earlier, Clara buys and smokes marijuana and seeks the company of a male escort after witnessing an orgy happening in one of the other apartments). As news of the classification spread, so did the reaction against it: without intention, the film had become, regardless of its subject matter, a forum for an essentially political (and broadly cultural) discussion. On the film's social media page, it was written that,

it is incredible to see that Aquarius is becoming the most controversial film of the year, apparently for celebrating life in a generous manner, for having a political and social point of view and for having as a lead character that thing that is scary for so many people: a strong woman [...] With this censorship, Aquarius becomes, strangely, even stronger!

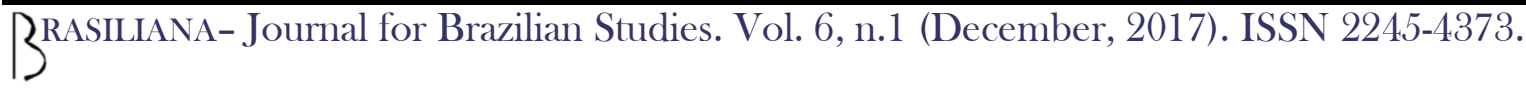


On the day of its release, the Ministry of Justice changed their mind under the pressure and opted for the age-16 classification, with the whole process only serving to bring more commercial and critical attention to the release.

In another example of the film's accidental politics out of the realm of subject matter, the choice of journalist and critic Marcos Petrucelli in August 2016 by the Ministry of Culture to head up the committee to choose Brazil's entry for the Academy Award for the Best Foreign Film category caused an outcry. Petrucelli had been vocal in his condemnation of the cast and crew of Aquarius on the red carpet of Cannes, and various industry professionals questioned the legitimacy of the nine-person committee that chose not to include Aquarius in the selection to be put forward to the Academy. The combination of the attempted classification for a higher age and the snub in even considering the film as among the preeminent Brazilian productions of the year raised questions over political maneuvering, leading three other prominent filmmakers to withdraw their films from the committee's list to decide on the Brazilian submission to the Best Foreign Film award. ${ }^{4}$

Petrucelli denied any wrongdoing, saying that he chose the film with the best chance of representing the country and claimed that the choice of jury members in the selection process was transparent. The film selected was Pequeno segredo, a romantic drama from director David Schurmann that was selected but not ultimately nominated, perhaps because it was seen, as one critic put it in the Folha de São Paulo, as "one of the worst Brazilian films of recent years" and "an ocean of clichés and sentimentality. The narrative is mushy, the visuals are mushy, the soundtrack is mushy, [and] the direction is an endless platitude" ${ }^{\prime 5}$. In those acutely politicized

\footnotetext{
4 These were Anna Muylaert's Mãe só há uma, Gabriel Mascaro’s Boi neon, and Aly Muritiba’s Para minha amada morte.

5 That reviewer goes on, "[the director of Pequeno segredo] is incapable of finding a framework that avoids simply repeating postcard images, TV images, or publicity. He lacks the punch to get from the actors a grand truth from behind the small secrets" in this "family drama." This quotation is my translation from Alcine Leite Neto's review of the movie in $A$ Folha de São Paulo on 13 September 2016. Intriguingly, both $O$ som ao redor and even more so Aquarius are also essentially family dramas but ones that actively and interestingly gesture towards something beneath the surface and move beyond stereotyped melodrama and away from spoon-fed narrative. Reviewers did not see it entirely unfavorably, but its directorial subtlety was never a prominent comment: in Veja it was received as "sensitive, dramatic film that promises tears and reflections," and in Globo (Rodrigo Ortega) as a "melodrama with obligated crying and feminine power [...] a film of clichés that is capable of captivating," in which emotional power comes not from anything implied but rather from how the film "lifts its arms, makes a sad face and, if allowed to, shouts into the viewer's ear to incentivize the tears." To complement the full range of reviews (and, by extension, to highlight the fickle, politicized, and subjective world of movie criticism), another reviewer-Luciano Trigo - said that it was "the best Brazilian film of recent years." That same critic, however, also said that not only might the
} 
moments in 2016, it seems that the committee opted for a film that was expressively and explicitly not politicized, one that instead fell back on tropes of clichéd sentimentality that might settle well with a wide range of the film-going public in Brazil and beyond. In tempestuous times the committee chose the safe option while in the process censoring the more ambitious film.

Petrucelli's position as the head of the committee was also clearly a political choice: he was a strong, vocal opponent of the outgoing president Dilma Rousseff and the PT. As soon as the cast and crew of Aquarius made their protest at Cannes in May-against what they understood as a "coup" but Petrucelli thought of as democratic political process-he reacted to their contestations that "Brazil is no longer a democracy" with a social media post that read:

Shame is the least you can say about the cast and crew of 'Aquarius' [...] Brazil's not a democracy? What sort of regime, then, is the one that allows the film's director to bring 30 people in his entourage on a vacation to the French Riviera? Not even Hollywood blockbusters attend Cannes with so many people.

By accusing them of malfeasance and implying that the film was a disappointment for its lack of awards and its political posturing, he further politicized the socio-cultural context in which the film existed. As he saw it (and again expressed on social media), a "film made with public funds [that] goes to Cannes and doesn't win any award" was a scandal, with the added "lie about the coup" only serving "to expose Brazil to ridicule."

For what is, essentially, a film about the redevelopment of an old building in the fourthlargest city in Brazil, the discursive tone surrounding it and its makers was by this point deeply controversial about what it meant in Brazil of the mid-2010s: it had become an object of political prominence. Petrucelli defended himself from what he termed as the "cinematographic left" in a column in A Folha de São Paulo on $11^{\text {th }}$ August, a couple of weeks after he was chosen as the head of the committee:

The problem is that the cinematographic left, this genre of Lulist realism in

film compete for the Best Foreign Film after rightly winning selection, but that it might also win. Unfortunately, many disagreed: after being put forward by the committee it was not selected for competition by the Academy.

BRASILIANA- Journal for Brazilian Studies. Vol. 6, n.1 (December, 2017). ISSN 2245-4373. 
national cinema, incessantly seeks to be vigilant and to be a victim. And to be the victim they need to find a culprit. Following that rationale, a critic who is part of the coup media [mídia golpista] becomes the favorite-or feared!-bad guy. If Aquarius doesn't go to the Oscars, it's obvious that it will be my fault.

He goes on to say that he only joined the committee to choose not only the best Brazilian film but also the one that has "real chances" of winning the Oscar, before aiming a final barb at this cinematographic left: why would they be so bothered with this statuette if all it is, after all, is “a prize offered precisely by that American imperialism so abominated by the left?". In that same article, he states that he is yet to see the film that he considers a coup-imagining, funddraining, politicized, victimized, leftist, anti-award production.

In the same newspaper just over a week later, the director responded with an open letter. "The question," he wrote, "is not about the Oscar [...] The question is about defending a democratic process." The "process" refers, perhaps, to the country more broadly and its recent impeachment, but here Mendonça Filho is directly referencing the process by which a federal body that is responsible with defending, stimulating, and promoting Brazilian culture needs to select a suitable committee that "must respect the democratic process of the Ministry of Culture". Technically, he writes, Petrucelli would be an able candidate given his experience; however, his political statements attacking Aquarius and his politicized presence on the cultural scene undermined the (supposedly democratic) selection process. Petrucelli, the critic-turnedcommittee head (from private to public and suddenly a figure of public importance and state employment) did not withdraw his personal opinions on politics and art from the public domain, and instead consistently took issue with the public opinions expressed by the makers of Aquarius. According to the director, Petrucelli's disdain with the film stems from "his personal dissatisfaction with democratic protest" that took place in Cannes rather than acting as the non-partisan head of a culture ministry.

This statement drew solidarity from colleagues who also felt that cultural expression and production was being undermined by politics. The team behind Boi neon was the first to respond, saying that it was,

regrettable that the Ministry of Culture [...] would endorse a committee member who has behaved in a barely professional and irresponsible manner in 
making these unsubstantiated statements [...] Aquarius was the only Latin American film in competition at Cannes, acclaimed by international media. Given the gravity of the situation and how these sort of precedents stifle creativity, we would like the register our discomfort with participating in a selection process of questionable impartiality.

The director Anna Muylaert, who had recently been appointed an Academy Member, followed suit, withdrawing Mãe só há uma from consideration, saying that "this is the year of Aquarius, the strongest film. Each year there's a clear candidate. Last year it was me, and I submitted as I thought it right. This year Aquarius is the correct choice," and that the biased and loaded choice of Petrucelli was controversial given his stated dissatisfaction not with the film and its story but with the political beliefs of the team behind it and the controversy it had generated. Another director, Aly Muritiba, then withdrew his film, writing on social media that,

We the team behind Para minha amada morta do not recognize the legitimacy of the commission put together by SaV [Secretário do Audiovisual] to choose the Brazilian representative for the 2017 Oscars. Therefore, we are withdrawing. In exceptional times it is necessary to take clear positions.

The multiple withdrawals also led two members of the nine-person committee to leave: the director Guilherme Fiúza Zenha and actor Ingra Liberato stepped down having seen the legitimacy of the committee questioned by substantial and influential parts of their profession. The Ministry of Culture defended its position, stating that its selections were free of political anglings and reaffirming its trust in the selection committee and process. Throughout these exchanges, often taking place on social media and largely absent of any real discussion of or even reference to the film and its direct subject matter, the film became a central feature of political debate in Brazil for its insinuations and for the questions it raised about the processes of democracy and censorship and how they manifest on the cultural landscape.

With these various protests in mind, it seems that Petrucelli's criticisms and opinions could be stomached when he was acting as a critic, which he was in May 2016. However, in July 2016, when he became a public official holding a prominent role, those objections became inherently more political and more objectionable: the state, and its recent political turn to the 
right and under suspicion by some as a hostile takeover, moved under the microscope for its role in politicizing this technically outstanding film. Aware of that transition that Petrucelli made between May and July, and also gesturing towards some off-point claims and implicating him in political scapegoating, Mendonça Filho questioned his position on the committee: "If this behavior as a journalist already makes his participation in this committee a little embarrassing for the $\mathrm{SaV}$, the question becomes more serious when some of his attacks publicly express lies," a reference to the trip to Cannes on the public dime, which-the director claimed - was not the case. For him, these claims mark "irresponsible behavior in a political moment in which the facts have already been ignored and distorted in the media" because many of the thirty people who were there as part of the two Pernambucan films at the festival paid their own way or raised money6. "There was nothing sinister in it. Sinister is the bad faith of a primitive character with internet access and without a sense of the information," the director wrote. After that stab, he concludes his letter by getting back to the film, highlighting its festival successes and distribution deals across platforms and territories - certainly more successful then Pequeno segredo - and stating its driving theme: "it's a film about loving people, being with them. It is also about the defense of a point of view, of an opinion based in facts and in life experiences through respect to the history of each person, and how this clashes with power."7

The film, therefore, is in its story a remarkably intimate and masterful portrayal by Braga of an older lady living in an apartment wondering what comes next. The forces that surround her-from family, from malicious developers, from unknown sources - are undeveloped but present, and became particularly recognized given the context in which the film was released. The film told the small-scale story of a physically and emotionally contested space (the building) and the film occupied an intensely contested space and challenged sense of place in the cultural geography of Brazil. As the director said in an interview with The New York Times in the aftermath of the film's red-carpet controversy in May 2016, "good films or books pick up

\footnotetext{
${ }^{6}$ That there were two Pernambucan films at Cannes is a remarkable feat in itself. The other was the short $O$ delírio $e$ a redenção dos aflitos by Fellipe Fernandes, the assistant director of Aquarius, screening in the International Critic's Week selection of short films.

${ }^{7}$ It is certainly worth remembering that it was the only Latin American-let alone Brazilian-film in the feature-length full competition that year at one of the world's premiere film festivals, which also serves as a hub for distributing deals and cultural capital.
}

3RASILIANA- Journal for Brazilian Studies. Vol. 6, n.1 (December, 2017). ISSN 2245-4373. 
on things in society, or in a country, but it is too early to say if this film does that before the film actually screens and people react to it. Only then will I know. I am curious myself." It certainly did do that: the discussion around the film intensified in the subsequent months and became a political point of reference that was symbolic of a broader malaise in Brazil and that also gestured towards an atmosphere of (moral) decadence and decay. In the process, Aquarius emerged as one of the most influential films in recent Brazilian history for its storytelling technique and style as well as for the coincidental timing of its release and the contextual circumstances. The contemporary relevance of this film is derived not only from the story it tells and its implications: it also comes from the context in which it was released, how it was received, and the manner in which the film itself became politicized as a testament to a moment of Brazil's history.

Away from the broader political context or the intricacies of the fictional story of the film, however, the building itself was salvaged by the import and impact of the film. In October 2016, the Board of the Preservation of Cultural Patrimony in Pernambuco opted to reassess whether to safeguard the historic Edificio Oceania, the principal setting for Aquarius, which a construction company started to buy up in 2003 with the intention of replacing it with a new, modern tower of the same style that has redefined Recife's cityscape in the past thirty years and chronicled by the black and white photos at the start of the film. While the developers decided not to demolish it after the resistance of residents, the building remains unprotected and faces an unknown future-in some ways, that building's fate can be seen as the conclusion of a film about contested spaces. With an insecure future and as a contested space in itself, the building still stands and now has a place on Recife's tourist map. It seems, for now at least, that if nothing else the film saved that real contested space in the actual geography of the city, even if the story was not fully resolved in a masterful fictional narrative that implied a great deal while leaving the connections to the viewer's imagination. Vitally, the film also captured the beginning of this tense political moment in post-boom Brazil, the moment in which the PT was removed from power and as tense political dynamics reemerged. As Brazil lurches deeper into crisis in 2018 and beyond, Aquarius is there to remind us that it did not come from nowhere. 


\section{References}

\section{Films}

Aquarius. Dir. Kleber Mendonça Filho. 2016.

O som ao redor. Dir. Kleber Mendonça Filho. 2012.

\section{Books}

Hemingway, Ernest. 1932. Death in the Afternoon. New York: Charles Scribner's Sons.

Iser, Wolfgang. 1978. The Act of Reading: A Theory of Aesthetic Response. Baltimore: Johns Hopkins University Press.

\section{Media \& Social Media}

"Anna Muylaert desiste de tentar vaga no Oscar em apoio a 'Aquarius.'” Globo G1, 24 August. http://g1.globo.com/pop-arte/cinema/noticia/2016/08/anna-muylaert-desiste-de-tentar-vagano-oscar-em-apoio-aquarius.html

“Boi Neon - Seleção brasileira ao Oscar 2017." Facebook, 24 August 2016. https://www.facebook.com/ValeuBoi/posts/1163479940385681:0

Carneiro, Raquel. "'Pequeno Segredo', aposta do Brasil ao Oscar, chega aos cinemas." Veja.com, 12 November 2016. http://veja.abril.com.br/entretenimento/pequeno-segredo-aposta-dobrasil-ao-oscar-chega-aos-cinemas/

Leite Neto, Alcino. "Clichê, 'Pequeno Segredo' é dos piores filmes brasileiros recentes." Folha de São Paulo, 18 September 2016. http://www1.folha.uol.com.br/ilustrada/2016/09/1812668cliche-pequeno-segredo-e-dos-piores-filmes-brasileiros-recentes.shtml

Mendonça Filho, Kleber. "'Além do comportamento constrangedor, crítico mente', diz diretor de 'Aquarius.'” Folha de São Paulo, 19 August 2016. http://www1.folha.uol.com.br/ilustrada/2016/08/1804377-alem-do-comportamento- 
$\underline{\text { constrangedor-critico-mente-diz-diretor-de-aquarius.shtml }}$

Muritiba, Aly. "Para minha amada morte." Facebook, 26 August 2016. https://www.facebook.com/photo.php?fbid=10208491602581512\&set=a.3064270239668.213119 9.1050852339\&type=3\&theater

Ortega, Rodrigo. "'Pequeno segredo' é melodrama com choro forçado e poder feminino." Globo G1, 23 September 2016. http://g1.globo.com/pop-arte/cinema/noticia/2016/09/pequenosegredo-e-melodrama-com-choro-forcado-e-poder-feminino.html

Petrucelli, Marcos. "E o Oscar vai para... o melhor filme brasileiro com chance real." A Folha de São Paulo, 11 August 2016. http://www1.folha.uol.com.br/ilustrada/2016/08/1801277-e-o-oscarvai-para-o-melhor-filme-brasileiro-com-chance-real.shtml

Rapold, Nicolas. "A Brazilian Filmmaker Travels Through Time, With Sonia Braga." New York Times, 10 May 2016. https://www.nytimes.com/2016/05/11/movies/a-brazilian-filmmakertravels-through-time-with-sonia-braga.html

Trigo, Luciano. “'Pequeno segredo' é o melhor filme brasileiro dos últimos anos.” Globo G1, 18 September 2016. http://g1.globo.com/pop-arte/blog/maquina-de-escrever/post/pequenosegredo-e-o-melhor-filme-brasileiro-dos-ultimos-anos.html 